\title{
SPATIAL DISTRIBUTION OF Pseudaletia sequax FRANCLEMLONT IN TRITICALE UNDER NO-TILL MANAGEMENT
}

\author{
Célia Regina Grego ${ }^{1 *}$; Sidney Rosa Vieira ${ }^{1}$; André Luiz Lourenção² \\ ${ }^{1}$ APTA/IAC - Centro de Pesquisa e Desenvolvimento de Solos e Recursos Ambientais, C.P. 28 - 13020-902 - \\ Campinas, SP - Brasil. \\ ${ }^{2}$ APTA/IAC - Centro de Fitossanidade. \\ *Corresponding author <crgrego@iac.sp.gov.br>
}

\begin{abstract}
The knowledge of the spatial distribution of insect populations in crops allows the estimation of the population density in space, the classification of damage impact on yield as well as decisions to be made about control measures. To evaluate the spatial distribution of the wheat armyworm Pseudaletia sequax Franclemont, in relation to the development and yield of triticale (Triticum secale Wittmack) under no-till management, samplings were taken at 302 points in a square grid measuring $10 \times 10 \mathrm{~m}$, in Campinas, SP, Brazil. The caterpillar population was evaluated by counting their number per meter at the base of triticale plants. Grain yield $\left(\mathrm{kg} \mathrm{ha}^{-1}\right)$, cover of the above-ground part $\left(\mathrm{kg} \mathrm{ha}^{-1}\right)$, mean plant height (m), and ground cover percentage were evaluated after the triticale crop was mechanically harvested, with the measurement of the mass of straw left on soil surface. Geostatistics was used to analyze spatial variability, by means of semivariogram analysis, and interpolation of data by both ordinary and indicator kriging, considering the injury threshold level of ten caterpillars per square meter to construct isoline maps. Spatial dependence occurred for all variables, demonstrating an aggregate spatial distribution pattern of the caterpillar in triticale. Random sampling in this area would fail to reveal that grain yield was affected at the location with the greatest occurrence of the caterpillar. At that location, the economic injury level was exceeded, which would justify the adoption of control measures against the pest.
\end{abstract}

Key words: Triticum secale Wittmack, Insecta, wheat armyworm, geostatistics, indicator kriging

\section{DISTRIBUIÇÃO ESPACIAL DE Pseudaletia sequax FRANCLEMONT NA CULTURA DO TRITICALE, EM PLANTIO DIRETO}

\begin{abstract}
RESUMO: O conhecimento da distribuição espacial de populações de insetos de uma cultura permite estimar a densidade populacional no espaço, classificar seus danos causados à produção e tomar uma decisão sobre a medida de controle. Assim, este trabalho foi desenvolvido com o objetivo de avaliar a distribuição espacial da lagarta do trigo Pseudaletia sequax Franclemont, em relação ao desenvolvimento e produção do triticale (Triticum secale Wittmack) em plantio direto, Campinas, SP. Foram realizadas amostragens em 302 pontos num reticulado quadrado de $10 \times 10 \mathrm{~m}$. Foi avaliada a população de lagartas pela contagem do número de lagartas por metro na base das plantas de triticale. Avaliou-se ainda a produção de grãos $\left(\mathrm{kg} \mathrm{ha}^{-1}\right)$, a quantidade de cobertura da parte aérea $\left(\mathrm{kg} \mathrm{ha}^{-1}\right)$, a altura média $(\mathrm{m})$ de plantas e a porcentagem de cobertura vegetal após a colheita mecanizada, permanecendo a palha na superfície do solo. Para analisar a variabilidade espacial, utilizou-se a geoestatística, através da análise de semivariogramas, interpolação dos dados por krigagem simples e indicatriz, considerando o nível de dano de dez lagartas por metro quadrado para construção de mapas de isolinhas. Ocorreu dependência espacial para todas as variáveis, evidenciando a distribuição espacial da lagarta de forma agregada na cultura do triticale. Amostragem ao acaso nesta área falharia em revelar que a produção de grãos foi afetada no local de maior ocorrência da lagarta. Nesse local, o nível de dano econômico foi ultrapassado, o que justificaria a adoção de medidas de controle da praga.

Palavras-chave: Triticum secale Wittmack, Insecta, lagarta-do-trigo, geoestatística, krigagem indicatriz
\end{abstract}

\section{INTRODUCTION}

Insects only become pests when they reach population levels that cause economic damage to the crop yield, justifying, in such situations, the applica- tion of control measures that can reduce the number of insecticide applications and preserve the natural enemy populations. Their spatial distribution, defined as the position that individuals occupy in space relative to each another, at a given focus (Vieira, 2000), influ- 
ences insect population dynamics. Differences in structure can be observed in relation to the sampled area, crop where they live (Knudsen et al., 1994), species (Nestel \& Klein, 1995), and developmental stage (Farias et al., 2001; Pereira et al., 2004). Insect spatial distribution studies have been performed using geostatistical analysis (Midgarden et al., 1993; Nestel \& Klein, 1995; Ellsbury et al., 1998; Pereira et al., 2004) and have shown that random distribution patterns rarely occur in nature. According to Jesus et al. (2002), the aggregate type of distribution is predominant, since these patterns are influenced by specific differences in each environment. According to Reis \& Miranda Filho (2003), these evidences compromise the validity and effectiveness of analysis models that assume independent errors. These studies allow population density estimates to be obtained and help control measures to be adopted more safely.

Many studies focus on the spatial distribution of insects, but few show results with regard to the development and yield of the affected crops. Among the pests that damage the aerial part of triticale (Triticum secale Wittmack), according to Gallo et al. (2002), Pseudaletia sequax Franclemont is one of the most important, due to defoliation and because of its difficult control. According to Gassen (2005), the economic injury level is ten caterpillars per square meter. The objective of this work was to evaluate the spatial distribution of $P$. sequax caterpillars in relation to triticale development and yield under no-till management.

\section{MATERIAL AND METHODS}

\section{Field experiment}

The field experiment was carried out at the "Centro Experimental" of the "Instituto Agronômico de Campinas" (IAC), SP, Brazil, and covers an area of $3.42 \mathrm{ha},\left(22^{\circ} 53^{\prime} \mathrm{S}\right.$ and $47^{\circ} 04^{\prime} \mathrm{W}$, at a mean elevation of $600 \mathrm{~m}$ above sea level) presenting a $6.5 \%$ slope. According to Oliveira et al. (1989) the soil is a clayeytextured Rhodic Eutrudox with a moderate A-horizon. According to Setzer (1966) international climate classification, the Campinas region presents a transition between the climatic types Cwa and Cfa, i.e., a tropical climate with a dry winter and a wet summer. The no-till management, system was adopted on area since 1985 , with summer and winter crops for the production of grain and ground cover.

Three hundred and two points $(10 \times 10 \mathrm{~m})$ were marked on the field for sampling in square grid (Figure 1). The triticale cultivar IAC 2 was sown as a winter crop in April 2004 under the no-till system. A spacing of $20 \mathrm{~cm}$ between rows was used, at a density of 60-70 seeds per meter. Fertilization at planting con- sisted of $150 \mathrm{~kg} \mathrm{ha}^{-1}$ of a 8-28-16 NPK formulation, following, soil analyses and recommendations of Raij et al. (1996). The crop was sprayed 32 days after seeding to control Sitobion avenae (Fabr.), with a 30-meter range cannon, using $2 \mathrm{~mL} \mathrm{~L}^{-1}$ monocrotophos, safety interval of 21 days, at a spray volume of $0.8 \mathrm{~L} \mathrm{ha}^{-1}$. The P. sequax population was evaluated 69 days after sowing, by counting the number of caterpillars found on the ground, around the base of the stem of plants, along one meter of row in each of the 302 points, to obtain the number of caterpillars per $\mathrm{m}^{2}$. At this time, the triticale was at the grain-filling stage.

The crop was harvested in September 2004, on a $1.5 \times 1.5 \mathrm{~m}$ plot $\left(2.25 \mathrm{~m}^{2}\right)$, and grain yield $\left(\mathrm{kg} \mathrm{ha}^{-1}\right)$, dry mass yield of the above-ground part $\left(\mathrm{kg} \mathrm{ha}^{-1}\right)$, and mean height $(\mathrm{m})$ were obtained for 10 plants per point. Percentage of residue ground cover was obtained after harvesting, using a $1 \mathrm{~m}^{2}$ square divided by lines into one hundred $0.1 \times 0.1 \mathrm{~m}$ sub-squares. The square was inserted at random into each of the 302 sampling points, and ground cover was estimated at the intersection points of lines that coincided with straw on the soil surface. Data were converted to percentage of ground cover on soil surface.

\section{Data analysis}

Data were initially analyzed by descriptive statistics, and mean, variance, standard deviation, coefficient of variation, maximum value, minimum value,

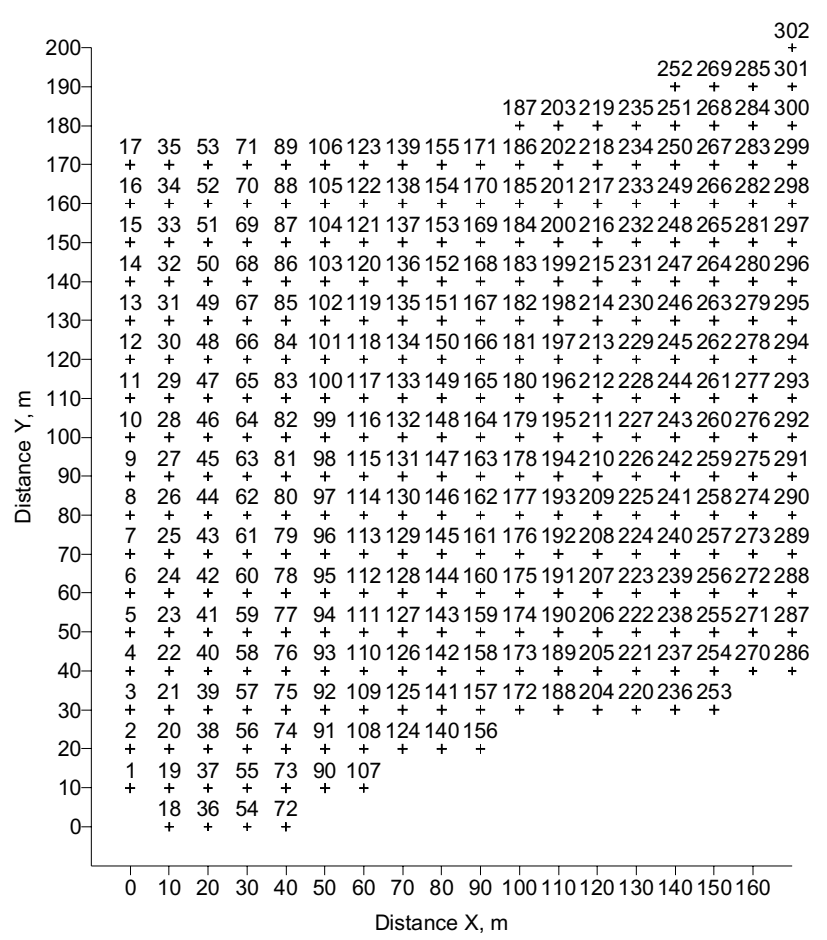

Figure 1 - Square sampling grid containing 302 points $(10 \times$ $10 \mathrm{~m})$. 
skewness, and kurtosis were obtained using the STAT software, according to Vieira et al. (2002). This analysis was carried out to detected outlier values and the frequency distribution of the data. When a set of data approaches the normal distribution, their skewness and kurtosis values approach zero; in this case, the central tendency value (mean) is equal to the measure that occurs most often (mode). If the skewness and kurtosis coefficients are greater than zero, the frequency distribution of data will tend to be lognormal, which is characterized by having a great number of small values, plus some values so large that will cause differences between the mean, the median, and the mode. This happens when the variable has a very localized distribution, i.e., there are sites with high values but the vast majority has low values.

To verify the spatial variability of variables, data were analyzed by semivariograms $\gamma(\mathrm{h})$, described by Vieira (2000), based on the assumptions of stationarity of the intrinsic hypothesis:

$$
\text { J(h) }\left.\frac{1}{2 N(h)}\right|_{1} ^{N} Z\left(x_{i}\right) \square Z\left(x_{i} \square h\right) @
$$

where $N(h)$ is the number of pairs of measured values $\mathrm{Z}\left(\mathrm{x}_{\mathrm{i}}\right), \mathrm{Z}\left(\mathrm{x}_{\mathrm{i}}+\mathrm{h}\right)$, separated by a vector $\mathrm{h}$, which is the distance determined from the $\mathrm{Z}\left(\mathrm{x}_{\mathrm{i}}\right)$ and $\mathrm{Z}\left(\mathrm{x}_{\mathrm{i}}+\mathrm{h}\right)$ coordinates. Calculation of equation (1) generates $\gamma(\mathrm{h})$ values corresponding to $\mathrm{h}$ distances, for the construction of the semivariogram. According to Vieira (2000), it is expected that measurements located near one another are more similar among themselves than those separated by great distances, i.e., where $\gamma(\mathrm{h})$ increases with the $\mathrm{h}$ distance until a maximum value at which it stabilizes, at a level corresponding to the limit distance of spatial dependence, which is the range. Measurements located at greater distances than the range have random distribution and are therefore independent among themselves; beyond this distance, classic statistics can be applied.

Mathematical models were fitted to the semivariograms, allowing the nature of spatial variation to be displayed for any distances within the measured field. The criteria and procedures for fitting the semivariogram models were made according to Vieira et al. (1983). Based on the model used to fit the data, the following semivariogram parameters were defined: a) nugget effect $\left(\mathrm{C}_{0}\right)$, which is the $\gamma$ value when $\mathrm{h}=0$; b) range of the spatial dependence (a), which is the distance at which $\gamma(\mathrm{h})$ remains approximately constant, after increasing as $\mathrm{h}$ increases constant; c) threshold $\left(\mathrm{C}_{0}+\mathrm{Cl}\right)$ which is the $\gamma(\mathrm{h})$ value beyond the range approaching the data variance, if it exists.
Spatial dependence can be expressed by the DD parameter (degree of spatial dependence), which is the proportion of structural variance $\left(\mathrm{C}_{1}\right)$ in relation to the threshold $\left(\mathrm{C}_{0}+\mathrm{C}_{1}\right)$, and can be calculated by the equation:

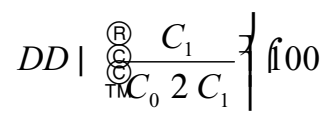

According to Zimback (2001), this can be used to classify the spatial dependence into weak if $\mathrm{DD}<$ $25 \%$; moderate for DD between $26 \%$ and $75 \%$; and strong if $\mathrm{DD}>75 \%$.

When semivariance is dependent upon distance, i.e., when spatial autocorrelation between samples exists, values can be interpolated in the study field, without bias and with minimum variance, using the kriging method described by Vieira (2000). Kriging is a technique used in geostatistics to estimate property values for locations where the property has not been measured. For this tool to be used it is required that the spatial dependence defined by the semivariogram exists (Vieira, 2000). Therefore, kriging is a process by which spatially-distributed property values are estimated from interdependent adjacent values (Vieira et al., 1983). The estimated value for the property, $\mathrm{Z}^{*}\left(\mathrm{X}_{0}\right)$, is given by the expression:

$$
Z^{*}\left(x_{o}\right) \prod_{i=1}^{N} Q_{i} Z\left(x_{i}\right)
$$

where $\mathrm{N}$ is the number of neighbors measured, $\mathrm{Z}\left(\mathrm{x}_{\mathrm{i}}\right)$ are used to estimate the property and $\lambda_{i}$ are the weights applied to each $\mathrm{Z}\left(\mathrm{x}_{\mathrm{i}}\right)$, which are selected so that the estimate obtained is unbiased. This implies assuming two conditions:

$$
\begin{aligned}
& E\left[Z^{*}\left(x_{o}\right) \square Z\left(x_{o}\right)\right] 0 \\
& V_{k}^{2}\left(x_{o}\right) \quad E\left[Z^{*}\left(x_{o}\right) \square Z\left(x_{o}\right)\right]^{2} \quad \text { minimum }
\end{aligned}
$$

Values interpolated by kriging were used to construct isoline maps for the variables under study as a function of their coordinates, using the Surfer program (Golden Software, 1999). The analysis of maps obtained via the kriging-estimated values allows the identification of sites with higher or lower occurrence of caterpillars or triticale grain yield.

The spatial variability in the number of caterpillars was also analyzed by indicator kriging (Goovaerts, 1997). Since the economic injury level is 10 caterpillars per square meter, levels of zero and one were established for values smaller and greater than ten, respectively, and values were interpolated and a 
map was constructed for caterpillar injury level in triticale, indicating the locations where control would be economically viable.

\section{RESULTS AND DISCUSSION}

Mean, variance, standard deviation, coefficient of variation (C.V.), minimum value, maximum value, skewness, and kurtosis (Table 1) indicated high variability for the caterpillar population, with a coefficient of variation in the order of $100 \%$. In terms of plant height, grain yield, and ground cover, low coefficients of variation were obtained, smaller than $30 \%$, according to criteria adopted by Warrick \& Nielsen (1980). Ground cover showed low coefficients of variation, $10.26 \%$, after harvesting the triticale, which could be attributed to the mass of straw distribution on the soil surface imposed by the harvesting machine.

The triticale crop grew under a very favorable condition in terms of water availability (Figure 2) and edaphic conditions, the main reason for the high grain $\left(2,660 \mathrm{~kg} \mathrm{ha}^{-1}\right)$ and dry mass (average 3,243 $\mathrm{kg} \mathrm{ha}^{-1}$ ) mean yields obtained, even when mean coefficient of variation $(34.72 \%)$ and the attack by $P$. sequax are taken into consideration (Table 1). The variables grain yield and dry mass yield showed normal distribution with skewness and kurtosis values near zero, except for plant height, which may indicate a lognormal distribution.
Semivariograms (Figure 3) and their fitted parameters (Table 2) indicate that the spatial dependence can be considered weak to moderate, with a high nugget effect, near the structural variance and with long range. The nugget effect indicates the variability at distances smaller than the sampling spacing $(10 \mathrm{~m})$ whose value include variability due to sampling errors and to point to point variation. Its value also reveals the amount of population aggregation in the spatial distribution with respect to sampling interval. The nugget effect values found are comparable to those presented by Ellsbury et al. (1998) for Diabrotica spp. in corn roots.

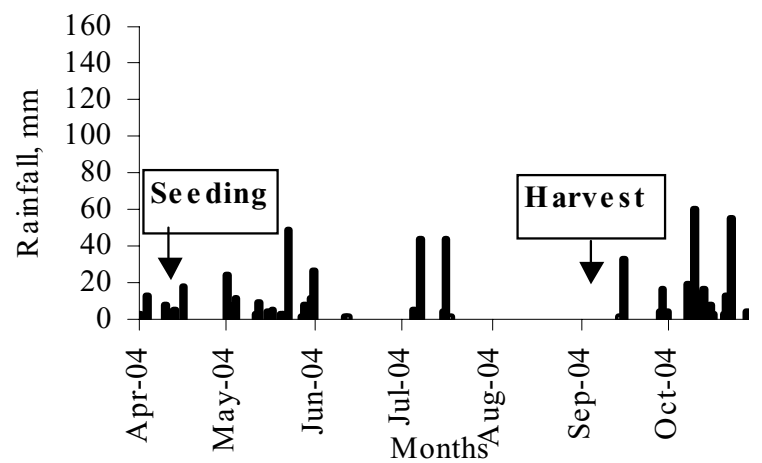

Figure 2 - Rainfall (mm) at "Centro Experimental Central", April 2004 to October 2004 indicating the times of seeding and harvest of triticale. Campinas, SP, Brazil.

Table 1 - Variable, unit, number of measurements, mean, variance, standard deviation (S.D.), coefficient of variation (C.V.), minimum value, maximum value, skewness, and kurtosis obtained in triticale infested with $P$. sequax. Campinas, SP. 2004.

\begin{tabular}{lccllllllrr}
\hline Variable & Unit & Number & Mean & Variance & S. D. & C.V. & Minimum & Maximum & Skewness & Kurtosis \\
\hline Caterpillar & $\mathrm{m}^{-2}$ & 300 & 21.3 & 460.3 & 21.46 & 100.7 & 0.00 & 100.0 & 1.130 & 1.180 \\
Caterpillar & Damage level & 300 & 0.580 & 0.240 & 0.49 & 84.7 & 0.00 & 1.00 & -0.340 & -1.900 \\
Plant height & meters & 295 & 1.102 & 0.004 & 0.064 & 5.8 & 0.92 & 1.56 & 1.046 & 8.312 \\
Grain yield & $\mathrm{kg} \mathrm{ha}^{-1}$ & 298 & 2,660 & 220.0 & 469.1 & 17.6 & 1,620 & 4,100 & 0.228 & 0.005 \\
Dry mass & $\mathrm{kg} \mathrm{ha}^{-1}$ & 293 & 3,243 & $1,268.0$ & 1,126 & 34.7 & 1,007 & 6,497 & 0.333 & -0.278 \\
Ground cover & $\%$ & 302 & 92.340 & 89.82 & 9.477 & 10.3 & 52.00 & 100.0 & -1.463 & 1.991 \\
\hline
\end{tabular}

Table 2 - Parameters of fitted semivariograms of variables obtained in triticale infested with P. sequax. Campinas, SP. 2004: Nugget effect $\left(C_{0}\right)$, structural variance $\left(C_{1}\right)$, range $(a)$, coefficient of determination $\left(r^{2}\right)$, weighted sum of squared deviations (WSSD), degree of dependence (DD), and fitted model.

\begin{tabular}{lrrrcccc}
\hline Variable & \multicolumn{1}{c}{$\mathrm{C}_{0}$} & \multicolumn{1}{c}{$\mathrm{C}_{1}$} & $\mathrm{a}$ & $\mathrm{r}^{2}$ & WSSD & DD & Model \\
\hline Caterpillar per $\mathrm{m}^{2}$ & 274.55 & 217.37 & 95 & 0.830 & 577.06 & 43.68 & Spherical \\
Caterpillar damage level & 0.130 & 0.110 & 90 & 0.830 & $1.24 \times 10^{-4}$ & 44.23 & Spherical \\
Plant height & 0.003 & 0.0004 & 25 & 0.114 & $7.00 \times 10^{-8}$ & 10.81 & Spherical \\
Grain yield & 150,000 & 75,000 & 80 & 0.380 & $1.96 \times 10^{+8}$ & 33.33 & Spherical \\
Dry mass & $591,979.9$ & $187,092.9$ & 15 & 0.0009 & $1.64 \times 10^{+9}$ & 24.01 & Spherical (residuals) \\
Ground cover & 58.000 & 40.000 & 70 & 0.660 & 23.99 & 40.82 & Spherical \\
\hline
\end{tabular}



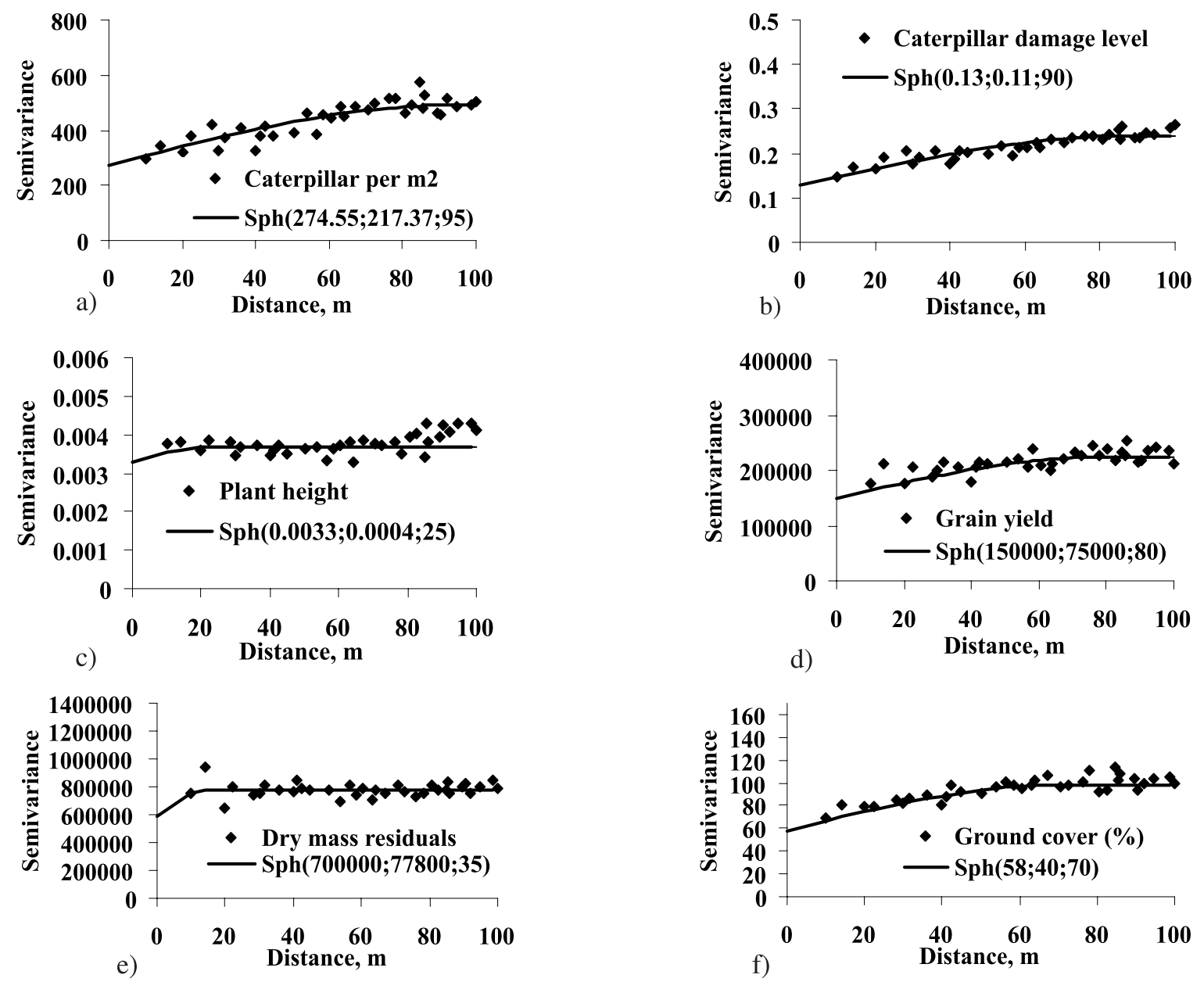

Figure 3 - Spherical-model fitted semivariograms, with nugget effect, structural variance and range (Sph Co; C1; a) of variables obtained in triticale infested by P. sequax. Campinas, SP, Brazil, 2004: a) caterpillars ( $\left.\mathrm{m}^{-2}\right)$, b) caterpillar (damage level), c) plant height (meters), d) grain yield $\left(\mathrm{kg} \mathrm{ha}^{-1}\right)$, e) dry mass residuals $\left.\left(\mathrm{kg} \mathrm{ha}^{-1}\right), \mathrm{f}\right)$ ground cover $(\%)$.

Height in triticale plants showed a smaller degree of spatial dependence (Table 2) and also a very low coefficient of variation (5.8\%) according to Table 1. This indicates that plant height had little spatial variation, i.e., it was extremely uniform in terms of height, and therefore it was not affected by the caterpillar, which caused defoliation when the plants probably had already reached their maximum growth. The obtained moderate degree of spatial dependence obtained justifies the sampling intensity adopted and is in agreement with results of insect spatial distribution studies (Farias et al., 2001; 2004, Jesus et al., 2002; Reis \& Miranda Filho, 2003), since occurrence of the caterpillar was of the aggregate form, not at random. It can also be observed that it was necessary to remove the linear tendency for a better characterization of the spatial variability to fit a model to the semivariogram of dry mass (Figure 3e). However, dry mass ranges on one direction can be perceived on the map as a result of that tendency (Figure 4).
Grain yield was visually reduced in places where there was greater caterpillar attack (Figure 4). In this case, an indicator kriging can map, with greater precision, regions of the field where chemical control should be necessary based on the injury level of 10 caterpillars per square meter. Notwithstanding, the attack was detrimental to grain yield in areas where the number of caterpillars exceeded the economic injury level.

Reported results can not be extrapolated to other fields and also for the description of the insect distribution in other conditions, as this was not the objective of the study. However, the ranges of the semivariograms for insect population $(95 \mathrm{~m}$ as shown in figure $3 \mathrm{a}$ ) and for the grain yield (80m as shown in figure $3 \mathrm{~d}$ ) indicate that the sampling interval of $10 \mathrm{~m}$ was adequate to characterize the insect population and the damage caused on grain yield. Therefore, the sampling distance used can adopted in other fields having similar conditions. 


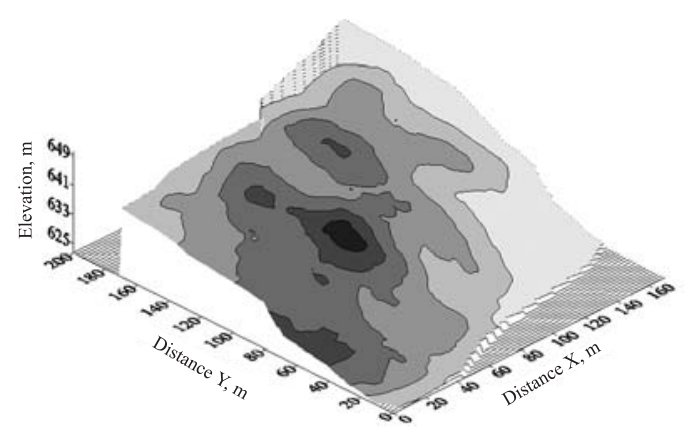

a)

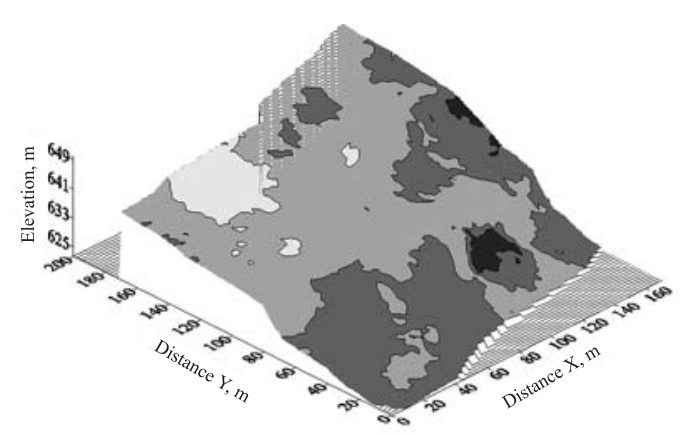

c)

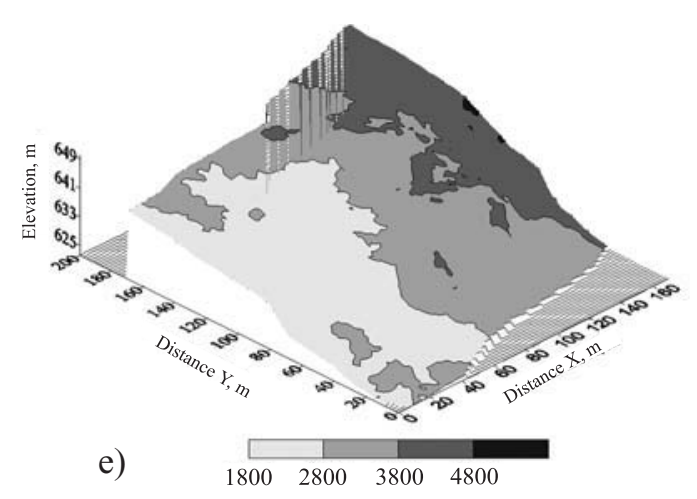

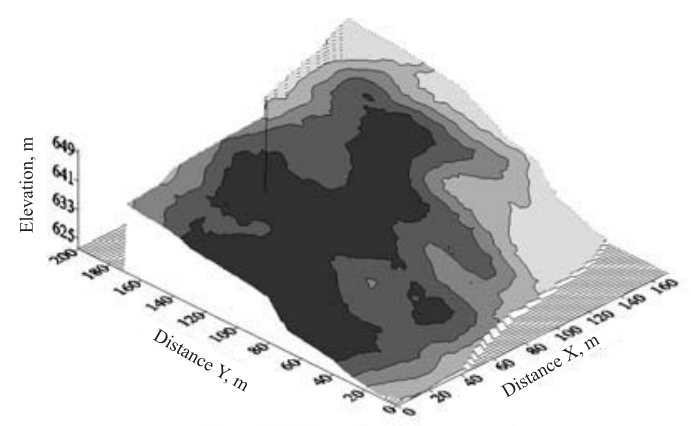

b)
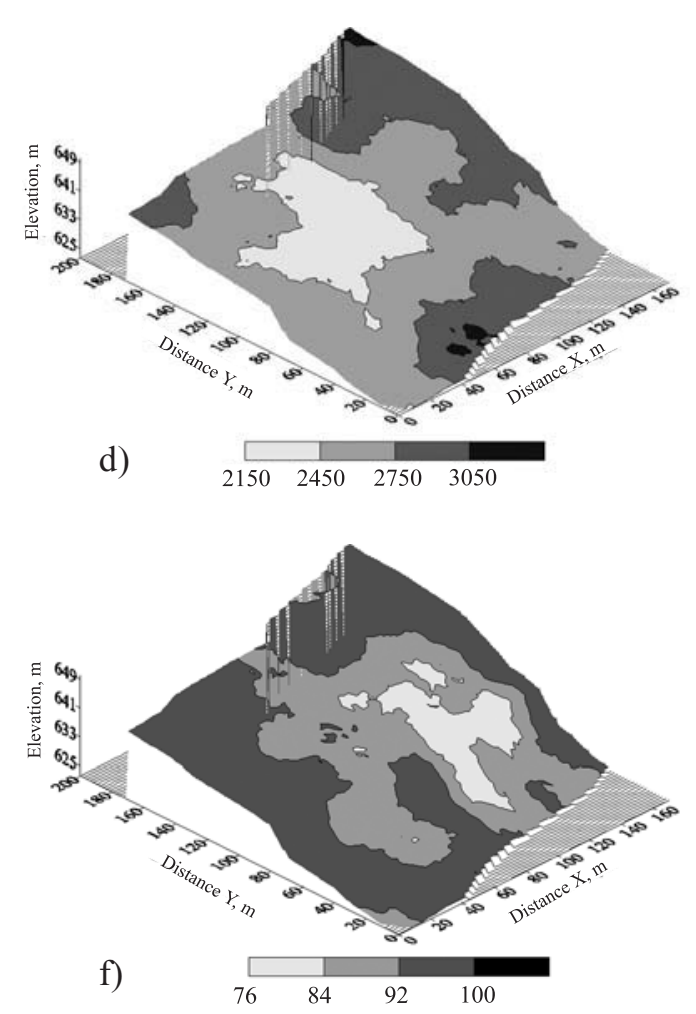

Figure 4 - Isoline maps of variables obtained in triticale infested with P. sequax. Campinas, SP, Brazil, 2004: a) caterpillars (m²), b) caterpillar (damage level), c) plant height (meters), d) grain yield $\left.\left(\mathrm{kg} \mathrm{ha}^{-1}\right), \mathrm{e}\right)$ dry mass $\left.\left(\mathrm{kg} \mathrm{ha}^{-1}\right), \mathrm{f}\right)$ ground cover $(\%)$.

\section{ACKNOWLEDGEMENTS}

To CNPq for a research fellowship granted to the first author and for research productivity fellowships granted to the other authors, and to FAPESP for financial support to this project.

\section{REFERENCES}

ELLSBURY, M.M.; WOODSON, W.D.; CLAY, S.A.; MALO, D.; SCHUMACHER, J.CLAY,D.E.; CARLSON, C.G. Geostatistical characterization of the spatial distribution of adult corn rootworm (Coleoptera: Chrysomelidae) emergence. Environmental Entomology, v.27, p.910-917, 1998.

FARIAS, P.R.S.; BARBOSA, J.C.; BUSOLI, A.C. Distribuição espacial da lagarta-do-cartucho, Spodoptera frugiperda (J.E. Smith) (Lepidoptera: Noctuidae), na cultura do milho. Neotropical Entomology, v.30, p.681-689, 2001.
FARIAS, P.R.S.; ROBERTO, S.R.; LOPES, J.R.S.; PERECIN, D. Geostatitical characterization of the spatial distribution of Xylella fastidiosa sharpshooter vectors on citrus. Neotropical Entomology, v.33, p.13-20, 2004.

GALLO, D.; NAKANO, O.; SILVEIRANETO, S.; CARVALHO, R.P.L.; BATISTA, G.C.; BERTI FILHO, E.; PARRA, J.R.P.; ZUCCHI, R.A.; ALVES, S.B.; VENDRAMIN, J.D.; MARCHINI, L.C.; LOPES, J.R.S.; OMOTO, C. Entomologia agrícola. Piracicaba: FEALQ, 2002. 920p.

GASSEN, D.N. Principais pragas nas culturas de trigo, cevada e aveia. Available in: www.cotrisoja.com.br/artigos/art-2005-0505.html. Accessed at: 09 Jun. 2005.

GOLDEN SOFTWARE. Surfer 7.0: Contouring and 3D surface mapping for scientist's engineers. User's Guide. New York, 1999. 619p.

GOOVAERTS, P. Geostatistics for natural resources evaluation. New York: Oxford University Press, 1997. 483p. (Applied Geostatistics Series).

JESUS, C.R.; REDAELLI, L.R.; ROMANOWSKI, H.P. Population dynamics and spatial distribution of Spartocera dentiventris (Berg) (Hemiptera: Coreidae) adults on Nicotiana tabacum L. (Solanaceae). Neotropical Entomology, v.31, p.541-549, 2002. 
KNUDSEN, G.R.; SCHOTZKO, D.J.; KRAG, C.R. Fungal entomopathogen effect on numbers and spatial patterns of the Russian wheat aphid (Homoptera: Aphididae) on preferred and nonpreferred host plans. Envirommental Entomology, v.23, p.1558-1567, 1994.

MIDGARDEN, D.G.; YOUNGMAN, R.R.; FLEISCHER, S.J. Spatial analysis of counts of Western corn rootworm (Coleoptera: Chysomelidae) adults on yellow sticky traps in corn. Geostatistics and Dispersion Indices, v.22, p.1124-1133, 1993.

NESTEL, D.; KLEIN, M. Geostitistical analysis of leafhopper (Homoptera: Cicadellidae) colonization and spread in deciduous orchards. Environmental Entomology, v.24, p.1032-1039, 1995.

OLIVEIRA, M.N.; OLIVEIRA, J.B.; LEPSCH, I.F. Mapa por compilação de solos do estado de São Paulo. Rio de Janeiro: EMBRAPA, SNLCS; IAC, 1989.

PEREIRA, M.F.A.; BOIÇA JR., A L.; BARBOSA J.C. Distribuição espacial de Bemisia tabaci (Genn.) biótipo B (Hemiptera: Aleyrodidae) em feijoeiro (Phaseolus vulgaris L.) Neotropical Entomology, v.33, p.493-498, 2004.

RAIJ, B. van; CANTARELLA, H.; QUAGGIO, J.A.; FURLANI, A.M.C. Recomendações de adubação e calagem para o estado de São Paulo. 2.ed. Campinas: Instituto Agronômico; Fundação IAC, 1996. 285p. (Boletim Técnico, 100).

REIS, A J.S.; MIRANDA FILHO, J.B. Autocorrelação espacial na avaliação de compostos de milho para resistência da lagarta do cartucho (Spodoptera frugiperda). Pesquisa Agropecuária Tropical, v.33, p.65-72, 2003.
SETZER, J. Atlas climático e ecológico do Estado de São Paulo. São Paulo: Comissão Interestadual da Bacia Paraná-Uruguai CESP, 1966. $57 \mathrm{p}$.

VIEIRA, S.R. Geoestatística em estudos de variabilidade espacial do solo. In: NOVAIS, R.F.; ALVAREZ, V.H.; SCHAEFER, G.R. (Ed.) Tópicos em ciência do solo. Viçosa: SBCS, 2000. v.1, p.1-54.

VIEIRA, S.R.; MILLETE, J.; TOPP, G.C.; REYNOLDS, W.D. Handbook for geostatistical analysis of variability in soil and climate data. In: ALVAREZ, V.V.H.; SCHAEFER, C.E.G.R.; BARROS, N.F.; MELLO, J.W.V.; COSTA, L.M. (Ed.) Tópicos em ciência do solo. Viçosa: SBCS, 2002. v.2, p.1-45.

VIEIRA, S.R.; HATFIELD, J.L.; NIELSEN, D.R.; BIGGAR, J.W. Geostatistical theory and application to variability of some agronomical properties. Hilgardia, v.51, p.1-75, 1983.

WARRICK, A.W.; NIELSEN, D.R. Spatial variability of soil physical properties in the field. In: HILLEL, D. (Ed). Applications of soil physics. New York: Academic Press, 1980. p.319-44.

ZIMBACK, C.R.L. Análise especial de atributos químicos de solo para o mapeamento da fertilidade do solo. Botucatu, UNESP, 2001. 114p. (Tese - Livre Docência).

Received December 20, 2005

Accepted June 18, 2006 